\title{
PENGEMBANGAN MODEL BELAJAR BERMUTU YANG ADAPTIF UNTUK MENINGKATKAN KINERJA GURU SEKOLAH DASAR TERPENCIL
}

\author{
Dodo Sutardi \\ FKIP Universitas Prof. Dr.Hazairin, SH. \\ Jl. A Yani No 1 Bengkulu. \\ E-mail: masdo.061960@gmail.com
}

\begin{abstract}
The purpose of this research is to produce excellent learning models which are adaptable and examine its effectiveness. The learning model is directed to increase teachers' performance in remote elementary schools. This research used two approaches which are; qualitative descriptive, and experiment with non-equivalent model control group design at four Elementary School within remote area in Seluma Regency, Bengkulu Province. The research results showed that (1)the Excellent Learning Model (PTK based teaching) adjusted with the limited teachers' academic qualification, learning infrastructure, the minimum training experience, low internal motivation, and (2) Adaptable Excellent learning model is more effective in increasing teachers' performance in remote area Elementary School.
\end{abstract}

Keywords: excellent learning model, adaptive, and teachers' performance

\begin{abstract}
Abstrak: Penelitian ini bertujuan (1) menghasilkan model belajar BERMUTU yang adaptif, dan (2) menguji keefektifan model belajar Bermutu yang adaptif dalam meningkatkan kinerja guru SD terpencil. Penelitian dilakukan pada 4 SD terpencil di Kabupaten Seluma Provinsi Bengkulu. Penelitian ini menggunakan dua pendekatan yaitu; deskriptif kualitatif, dan eksperimen dengan model noequivalent control group design. Hasil penelitian: (1) Model belajar Bermutu (pembelajaran berbasis PTK) disesuaikan dengan keterbatasan kualifikasi akademik guru, sarana prasarana pembelajaran, minimnya pengalaman pelatihan, motivasi internal yang rendah, dan (2) Model pembelajaran Bermutu yang adaptif lebih efektif dalam meningkatkan kinerja guru SD terpencil.
\end{abstract}

Kata kunci: model pembelajaran bermutu, adaptif, dan kinerja guru

Model belajar Better Education through Reformed Management and Universal Teacher Upgrading (BERMUTU) merupakan model penerapan penelitian tindakan kelas oleh guru yang diarahkan pada upaya pemecahan masalah atau perbaikan pembelajaran. Bermutu, merupakan program kerjasama antara Pemerintah Indonesia, Pemerintah Belanda, dan Bank Dunia yang diselenggarakan dari tahun 2008 sampai dengan 2013. Tujuan program ditujukan untuk meningkatkan mutu pendidikan melalui peningkatan kompetensi dan kinerja guru. Oleh karena itu, salah satu kegiatannya adalah memberikan pelatihan model pembelajaran berbasis Penelitian Tindakan Kelas (PTK), yang lebih dikenal dengan model belajar "BERMUTU".

Program yang dikelola oleh Direktorat Jenderal Peningkatan Mutu Pendidik dan Tenaga Kependidikan (PMPTK), Direktorat Pendidikan Tinggi, Badan Penelitian dan Pengembangan (Balitbang) Pendidikan, Menteri Pendayagunaan Aparatur Negara dan Reformasi Birokrasi (MENPANRB), dan Badan Kepegawaian Negara (BKN) ini 
dinilai berhasil dan berdampak positif terhadap peningkatan mutu pendidikan di 75 kabupaten/ kota, demikian disampaikan dalam Siaran Program BERMUTU di TVRI, pada hari Kamis, 24 Oktober 2014. Namun demikian, ada indikasi bahwa, media pembelajaran disusun dengan tidak memperhatikan tingkat kemampuan guru di daerah terpencil yang sangat terbatas karena akses perkembangan ilmu dan teknologi (kemampuan guru di kota dan desa diasumsikan sama), pelaksanaan pelatihan tidak mengakomodir keterbatasan-keterbatasan sarana prasarana khususnya pada SD di daerah terpencil, (hasil moitoring peneliti ketika menjadi konsultan pada program BERMUTU). Penelitian yang dilakukan Alwani (2012:69) tentang implementasi program Kelompok Kerja Guru (KKG) BERMUTU dalam meningkatkan kompetensi guru, menyimpulkan bahwa faktor-faktor penghambat implementasi Program BERMUTU, antara lain tidak adanya sarana dan prasarana yang memadai, kurangnya pemahaman guru terhadap materi program. Permasalahan lain adalah bahwa pelatihan model pembelajaran BERMUTU cenderung bersifat monoton, kurang variatif, dan cenderung hanya mengejar target akhir yang berupa penyelesaian tagihan-tagihan dengan mengabaikan substansi dari tagihan-tagihan tersebut. Nara sumber juga kurang berkualitas dalam memotivasi peserta untuk mengikuti kegiatan.

Indikasi-indikasi keterbatasan yang demikian, melatarbelakangi diperlukannya pengembangan model pembelajaran BERMUTU adapatif untuk meningkatkan kinerja guru SD terpencil. Penelitian ini bertujuan: (1) menghasilkan model belajar BERMUTU yang adaptif dengan situasi dan kondisi serta keterbatasan pembelajaran di SD terpencil, 2) teruji keefektifan model belajar Bermutu adaptif dalam meningkatkan kinerja guru SD terpencil. Dengan demikian diharapkan peningkatan kompetensi atau kinerja guru tidak hanya diupayakan oleh guru SD di perkotaan, tetapi juga oleh guru SD di daerah terpencil.

Perbedaan mendasar antara model belajar BERMUTU dengan model yang adaptif tidak pada tataran konsep, tetapi pada aplikasi dilapangan. Jika dalam pelatihan model pembelajaran BERMUTU menggunakan pendekatan pedagogik maka dalam model yang adaptif digunakan pendekatan andragogi dan partisifatif. Sutisna (2011:76), menegaskan, bahwa belajar dengan pendekatan pedagogik berlandasakan pada behavioristic theories dimana peserta pelatihan diintervensi dan dibentuk perilakunya sebagai guru yang memiliki keterampilan melaksanakan pembelajaran yang lebih baik. Adapun belajar dengan pendekatan andragogi dan partisipatif termasuk dalam teori humanistis (humanistic theories), peserta pelatihan diperlakukan sebagai orang dewasa yang kaya pengalaman, mempunyai konsep diri, orientasi pembelajaran untuk mengatasi masalah dan hasil pelatihannya bisa langsung diaplikasikan.

Model belajar BERMUTU sebagai sebuah program pelatihan, telah dilengkapi seperangkat bahan belajar untuk meningkatkan kualitas guru, yaitu bahan belajar bidang ilmu untuk guru SD dan Sekolah Menengah Pertama (SMP). Bahan belajar dikembangkan dengan melibatkan sejumlah widyaiswara dari Pusat Pengembangan dan Pemberdayaan Pendidik dan Tenaga Kependidikan (P4TK), dosen Lembaga Pendidikan Tenaga Kependidikan (LPTK), guru, kepala sekolah, dan pengawas sekolah, serta mengintegrasikan berbagai masukan dari praktisi lapangan dan nara sumber ahli dari LPTK, dimanfaatkan sebagai perangkat utama dalam proses pendidikan dan pelatihan bagi guru di KKG/MGMP. Bahan belajar dirancang dengan mengintegrasikan pendekatan penelitian tindakan kelas, lesson study, dan studi kasus, diharapkan dapat memandu guruguru untuk melakukan kajian kritis terhadap proses pembelajaran yang dilaksanakan, memperbaiki dan mengembangkan kurikulum pembelajarannya, serta mempraktikkan pembelajaran yang baik berdasarkan metode Pembelajaran Aktif Inovatif Kreatif Efektif Menyenangkan (PAIKEM) dan strategi pembelajaran inovatif lainnya. Tujuan pengembangan bahan belajar adalah untuk memberikan kesempatan kepada guru untuk terlibat dalam proses pengembangan profesional secara berkelanjutan melalui kegiatan KKG, MGMP, (DP3, 2008:vii).

Secara khusus, Model Belajar BERMUTU ditujukan untuk dapat meningkatkan keterampilan guru dalam: (1) melakukan penelitian tindakan kelas dengan Lesson Study secara berkelanjutan sebagai upaya untuk memahami proses belajar mengajar pada pendidikan dasar, (2) mengembangkan kurikulum dan perencanaan pembelajaran sesuai dengan aturan yang berlaku bagi jenjang pendidikan dasar kelas awal, pendidikan dasar kelas tinggi, dan pendidikan menengah pertama, (3) menambah wawasan bidang ilmu berdasarkan permasalahan keilmuan 
yang muncul dalam rangka penerapan kurikulum sekolah pada SD dan SMP, (4) melaksanakan proses pembelajaran inovatif berbasis penelitian tindakan kelas dan Lesson Study dalam mata pelajaran di sekolah pada SD dan SMP, (5) memanfaatkan beragam sumber belajar berbasis teknologi informasi dan komunikasi untuk pengembangan diri, proses pembelajaran, dan sumber belajar mata pelajaran di sekolah (bermutu_diknas@yahoo.com). Dalam kaitan ini guru hendaknya memiliki keahlian khusus dan dapat menguasai skill profesinya, terutama dalam proses pembelajaran di kelas dan peran guru yang lebih spesifik sifatnya (Susilawati, 2014:144).

Model belajar BERMUTU menekankan pada kajian pembelajaran sebagai langkah awal untuk membuka cakrawala guru tentang proses pembelajaran dari tiga aspek, yaitu aspek kurikulum, aspek bidang studi, dan aspek praktik pembelajaran. Melalui kajian pembelajaran, dimana guru melakukan observasi dan menganalis proses pembelajaran yang berlangsung secara cermat, guru diharapkan dapat mengidentifikasi beragam masalah dalam proses pembelajaran, terutama dari sisi kurikulum, bidang studi, dan praktik pembelajaran. Oleh karena itu materi pelatihan terdiri atas 6 langkah penelitian tindakan kelas, yaitu: (1) kajian pembelajaran, (2) identifikasi masalah dan rencana tindakan, (3) pelaksanaan tindakan dan observasi, (4) pengumpulan dan analisis data, (5) repleksi dan tindak lanjut, serta (6) pelaporan. Keenam langkah itu digambarkan pada gambar 1.
Adapun beberapa hasil penelitian yang mengatakan bahwa, Faktor sikap, inisiatif, kreatifitas, inovasi sangat mendukung keberhasilan pelaksanaan KBK karena pendekatan dan metode yang digunakan beragam, bersifat kontektual dan guru bukan satu-satunya sumber ilmu pengetahuan serta hal tersebut meningkatkan kinerja guru (Hanafi \& Yuliani, 2006; Hurmaini, 2011, Aritonang, 2005). Selain itu, para guru harus memperhatikan berbagai faktor yang bersumber pada komponen masukan, proses, dan keluaran agar menjadi guru yang profesional dan berkinerja tinggi. Ciri guru seperti inilah yang dibutuhkan dalam era informasi dan globalisasi sebagai cermin guru yang bermutu (Nurhayati, 2006; Khodijah, 2013; Bahri, 2011).

\section{METODE}

Penelitian ini dirancang untuk mengembangkan model belajar BERMUTU yang adaptif bagi guru-guru SD terpencil di Provinsi Bengkulu, untuk itu digunakan model Research and Development (R\&D) (Neuman, 2013, Sugiyono 2011:298). Data awal yang digunakan untuk pengembangan model adalah kondisi dan situasi serta keterbatasan sarana prasarana, keterbatasan kualifikasi, juga kinerja guru SD terpencil yang akan dijadikan dasar pengembangan model. Setelah data dianalisis menggunakan model Miles and Huberman (Sugiyono, 2011:247) selanjutnya dikembangkan model belajar BERMUTU adaptif, untuk kemudian

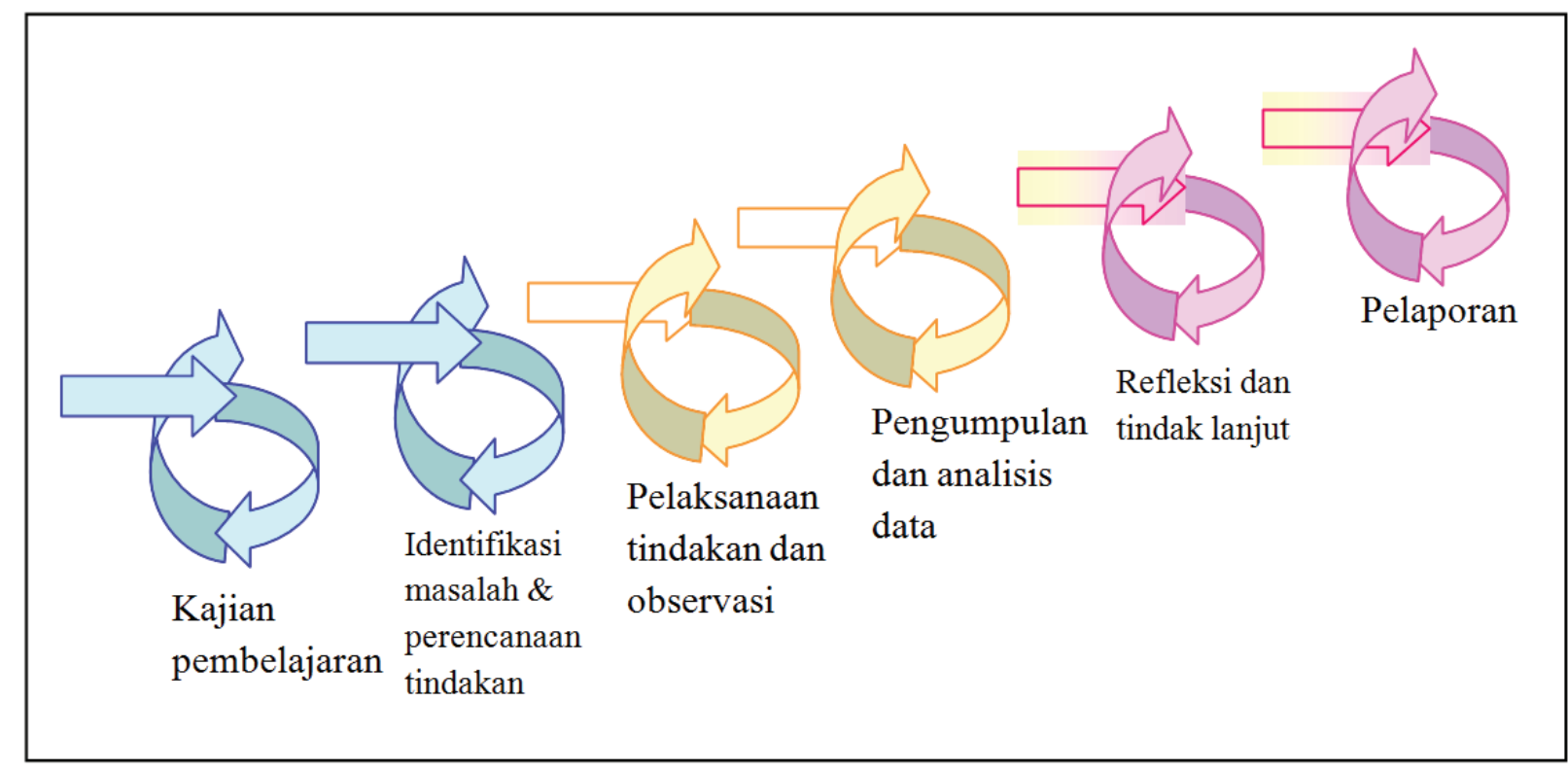

Gambar 1: Langkah-langkah Pembelajaran Berbasisi PTK, dikutip dari Bahan Belajar Mandiri BERMUTU 
diuji secara teoritik maupun empirik yang dilakukan melalaui: (a) konstruk teoritik, (b) validasi Pakar dalam bentuk forum group discussion (FGD), dan (c) uji coba.

Untuk melakukan uji coba sampel diambil secara purposif, sampel diambil berdasarkan kreteria yang menunjang pencapaian tujuan penelitian. Oleh karena itu, model eksperimen yang digunakan adalah Nonequivalent Control Group Design (Montgomery, 2001, Sugiyono, 2011:79). Untuk menentukan kelas kontrol dan eksperimen tidak dilakukan secara ramdom, melainkan dipilih dari kelompok guru SD terpencil sebanyak 40 orang (guru di 4 SD terpencil yang memiliki kesamaan dalam kondisi dan situasi sekolah, yakni akses sekolah dari kota kecamatan ke SD terpencil, kualifikasi guru, sarana prasaran, pengalaman pelatihan program BERMUTU). Ke 40 guru tersebut dibagi dua; 20 orang sebagai kelompok kontrol, dan 20 orang sebagai kelompok eksperimen. Pelatihan untuk masing-masing kelompok dilakukan sebanyak 8 kali pertemuan dengan tahapan kegiatan sesuai dengan skenario. Data hasil uji coba dianalisis menggunakan rumus uji $\mathrm{t}$ untuk mengetaui kefektifan model belajar BERMUTU adaptif dalam meningkatkan kinerja guru SD terpencil.

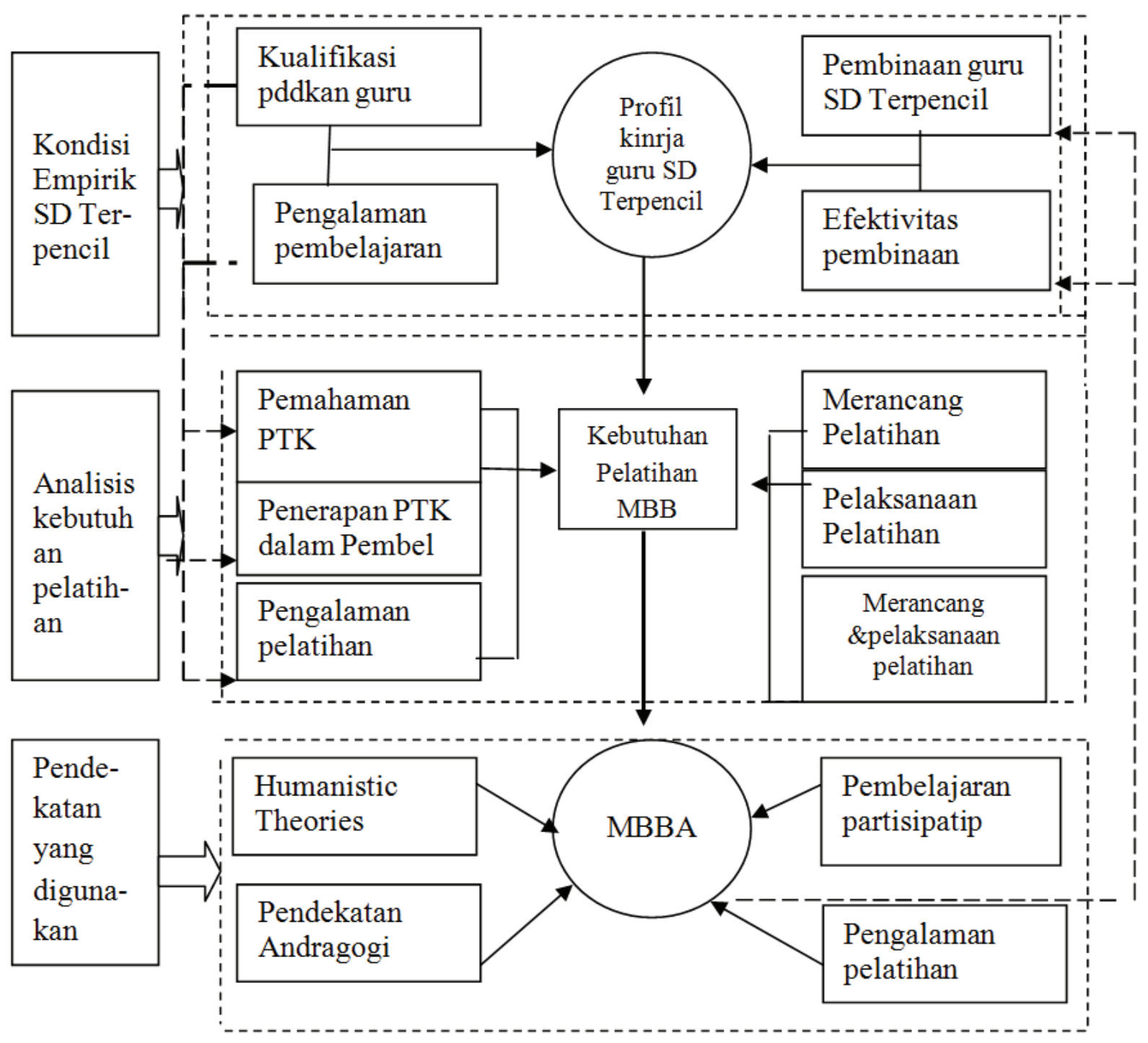

Gambar 2. Alur Berpikir Kebutuhan Pengembangan Model Belajar BERMUTU yang Adaptif (dikembangkan dari model Pelatihan Berbasis Kinerja, Sutisna, 2011:87) 


\section{HASIL DAN PEMBAHASAN}

Mengembangkan model belajar BERMUTU yang adaptif, terlebih dahulu dilakukan identifikasi situasi dan kondisi, keterbatasan-keterbatas sarana prasarna serta profil guru-guru di SD terpencil yang akan dijadikan dasar dalam pengembangan model, meliputi: (1) profil guru SD terpencil yang dijadikan sampel penelitian meliputi kualifikasi akademik dan profil kinerjanya; (2) model pelatihan dan strategi peningkatan kinerja guru SD terpencil di Provinsi Bengkulu; (3) kondisi pembelajaran di SD terpencil; dan (4) ketersediaan sarana dan prasaran pendudukung pembelajaran.

Setelah keempat poin tersebut teridentifikasi, kemudian dilakuan analisis kebutuhan pengembangan model belajar BERMUTU yang adaptif, dengan alur berfikir pada gambar 2 .

Kondisi empirik SD terpencil di Provinsi Bengkulu hasil identifikasi melalui pendekatan kualitatif, dapat digambarkan sebagai berikut: (1) masih terdapat guru yang belum berkualifikasi S1, (lulusan SLTA, D1, D2, dan D3); (2) kinerja guru diukur dari kemampuan memahami dan mengaplikasikan pembelajaran berbasis PTK, kinerja guru SD terpencil masih rendah; dan (3) pada umumnya guru SD terpencil masih terbatas dalam mengikuti pelatihan-pelatihan untuk peningkatan kinerja. Guru yang mendapatkan kesempatan untuk mengikuti pelatihan pembelajaran berbasis PTK, hanya guru-guru senior (PNS) yang ditugaskan oleh Diknas Kabupaten.

Kondisi pembelajaran di SD terpencil pada umumnya kurang kondusif. Penyebabnya antara lain; (a) banyak guru yang berkualifikasi S1 dan berstatus PNS, membebankan tugas mengajarnya pada guru honor yang notabene tidak memiliki kualifikasi dan pengalaman bidang pendidikan, dan (b) karena akses yang sulit, guru-guru sering tidak mengajar, sementara guru yang tinggal dekat sekolah umumnya guru honor yang terbatas baik kualitas maupun kuantitas.

Kondisi pembelajaran di SD terpencil dapat diupayakan melalui pengangkatan guru-guru yang memenuhi syarat kualifikasi, atau mempermudah akses, tetapi upaya itu memerlukan waktu yang lama. Sementara kebutahan akan pelayanan pembelajaran yang kondusif di daerah terpencil tidak dapat ditunda-tunda, maka salah satu upaya adalah mendidik atau melatih guru-guru untuk memiliki kompetensi dan kinerja yang memadai. Model belajar BERMUTU adalah cara yang diupayakan untuk meningkatkan kinerja guru melalaui pelatihan penerapan PTK dalam pembelajaran. Berdasarkan hasil penelitian Basuki (2013) menunjukkan bahwa jenis kegiatan yang dilakukan guru untuk kegiatan kependidikan, baik pada jam kerja sekolah maupun di luar jam kerja sekolah meliputi kegiatan merencanakan pembelajaran, melaksanakan pembelajaran tatap muka, melakukan penilaian, membimbing kegiatan siswa, melakukan pekerjaan tambahan dan melakukan pengembangan profesi kependidikan. Program ini dalam pelaksanaannya tidak mengakomodir keterbatasan-keterbatasan SD terpencil seperti digambarkan di atas. Maka mengembangkan model belajar BERMUTU yang adaptif diperlukan, sehingga konsep-konsep yang telah dirancang dapat diaplikasikan oleh guru-guru SD terpencil.

Beberapa aspek yang dijadikan pertimbangan dalam mengembangkan Model Belajar BERMUTU yang adaptif, yakni: (1) rasionalisasi, bahwa pelatihan Model Belajar BERMUTU yang adaptif menjadi alternatif bagi peningkatan kinerja guru SD terpencil, dengan tujuan agar kinerja guru SD terpencil meningkat; (2) asumsi bahwa kondisi empirik pengalaman pelatihan dan kinerja guru SD terpencil, mengharuskan dikembangkannya model Belajar BERMUTU yang adaptif; (3) tujuan, meningkatkan motivasi internal dan kinerja guru SD terpencil; (4) komponen-komponen pembelajaran dalam pelatihan, meliputi peningkatan motivasi internal melalui tayangan film yang menggambarkan kekuatan motivasi internal guru di SD terpencil, konsep PTK dalam pembelajaran, langkah-langkah pembelajaran dengan pendekatan PTK, penyusunan karya tulis ilmiah (sesuai dengan kemampuan guru); (5) penyampaian materi dikembangkan dengan menggunakan pendekatan andragogik dan partisipatif; (6) pengorganisasian fleksibel, disesuaikan dengan kondisi dan situasi guru-guru SD terpencil; dan (7) indikator keberhasilan, yaitu menurunkan kemangkiran, meningkatkan pemahaman guru akan pembelajaran berbasis PTK, meningkatkan kemampuan guru dalam mengkaji pembelajaran (kajian kritis), identifikasi masalah pembelajaran dan merencanakan pembelajaran, dan melaksanakan pembelajaran berbasis PTK, dan menyusun karya ilmiah tentang pembelajaran. Berdasarkan model konseptual tersebut, maka alur pelatihan model belajar BERMUTU yang adaptif dalam aplikasi dilapangan digambarkan pada gambar 3 . 


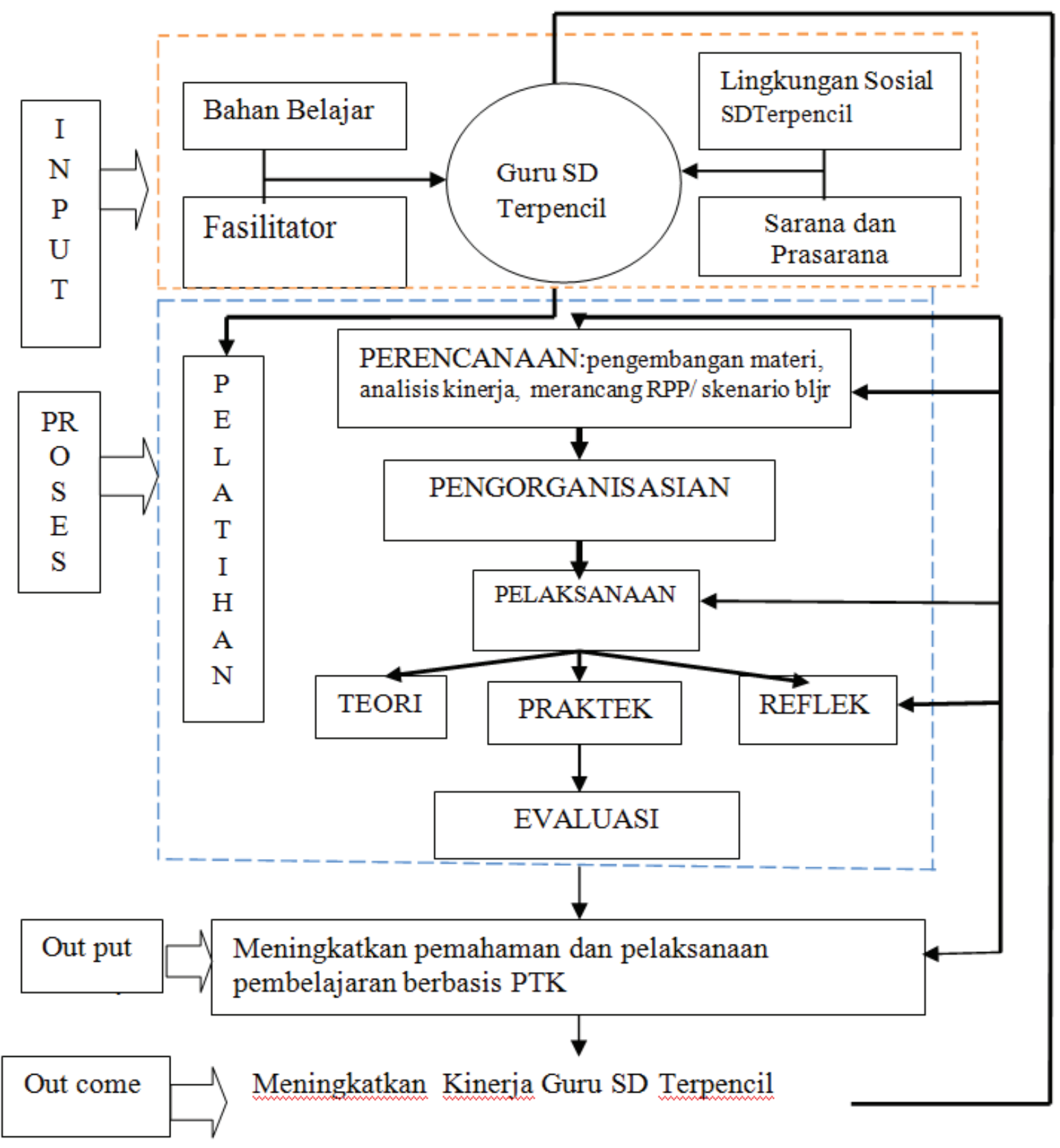

Gambar 3: Alur Berpikir Pelatihan Model Belajar BERMUTU yang Adaptif

Model belajar BERMUTU adaptif dikembangkan untuk mengakomodir fakta empirik kondisi situasi dan segala keterbatasan di SD terpencil. Oleh karena itu yang dijadikan dasar/input pengembangan model adalah kondisi dan situasi lingkungan sosial SD terpencil, keterbatasan sarana prasarana, pengalaman guru dalam melaksanakan pembelajaran berbasis PTK. Setelah model belajar BERMUTU hasil pengembangan didiskudsikan melalaui forum group discussian, maka disusun skenario pelatihan Model bejar BERMUTU, dan model belajar BERMUTU adaptif.

\section{Skenario Pelatihan Model Belajar BERMUTU}

Pelatihan dilaksanakan dengan asumsi semua guru memiliki kemampuan dan kesiapan yang sama untuk dilatih dan untuk menjadi guru berkompeten. Pendekatan yang digunakan adalah pendekatan paedagogik, artinya peserta diupayakan untuk mengikuti aturan-aturan yang terukur, untuk itu 
jika ada pelanggaran maka secara individu atau kelompok dikenai sangsi (pengorganisasian sesuai dengan aturan-aturan yang berlaku). Peserta adalah semua guru SD terpencil di Kecamatan Lubuk Sini Kabupaten Seluma. Pelatihan dipusatkan di Kantor UPTD Diknas. Materi, berdasarkan panduan yang telah ditentukan pusat, Materi pelatihan PTK, ICT, Pendalaman Ilmu. Pelatihan dilaksanakan 4 hari berturut-turut, selama 2 bulan, dengan langkahlangkah kegiatan sebagai berikut:

Pertemuan pertama menghadirkan Kepala UPTD, Kepala Sekolah, Pengawas (disampaikan aturan-aturan pelatihan, termasuk sangsi-sangsi atas pelanggaran). Pertemuan berikutnya dilakukan sesuai dengan rancangan dan jadwal pelatihan yang telah disusun. Proses kegiatan setiap pelatihan merujuk pada pendekatan paedagogik yang cenderung monoton. Diawali dengan penyampaian materi oleh instruktur, dilanjutkan dengan tanya jawab tentang materi pelatihan, dan kegiatan diakhir dengan latihan merumuskan materi yang telah disampaikan. Misalnya meteri pelatihan membahas tentang Identifikasi dan Batasan Masalah, maka peserta diminta untuk mengajukan masalah dengan menguraikan Identifikasi dan Batasan Masalah. Apabila guru-guru kurang mampu mengerjakan tugas pada saat melakukan pelatihan, maka latihan dilanjutkan dengan memberikan tugas rumah yang harus dikumpulkan pada pelatihan hari berikutnya. Hari kedua sampai dengan keempat pelatihan membahas dan menyelesaikan materi yang telah ditentukan (harus selesai, tanpa mengukur tingkat penyerapan materi oleh peserta). Jadwal dan materi pelatihan sesuai dengan pedoman jadwal pada tabel 1.

\section{Skenario Pelatihan Model Belajar BERMUTU Adaptif}

Rasionalisasi, bahwa pelatihan Model Belajar BERMUTU yang adaptif menjadi alternatif bagi peningkatan kinerja guru SD terpencil., maka disusun skenario pelatihan model belajar BERMUTU adaptif. Tujuannya agar kinerja guru SD terpencil meningkat. Skenario tersebut adalah sebagai berikut: (1) pelatihan dilaksanakan dengan mempertimbangkan fakta empirik kondisi dan situasi guru SD terpencil: kualifikasi pendidikan, kemangkiran guru karena kondisi dan situasi daerah, keterbatasan sarana prasarana, keterbatasan dalam mengikuti pelatihan, pengalaman mengajar; (2) materi pelatihan dikembangkan dengan pertimbangan pengalaman mengajar dan kualifikasi akademik (dibicarakan bersama dengan peserta). Proses pembelajaran berlandaskan pada konsep andragogik dan partisipatif, belajar berpusat pada masalah, peserta didorong untuk aktif, melibatkan

\section{Tabel 1. Jadwal dan Proses Kegiatan Pelatihan Kelompok Kontrol}

\begin{tabular}{|c|c|c|c|}
\hline $\begin{array}{l}\text { Bulan } \\
\text { ke: }\end{array}$ & $\begin{array}{c}\text { Pertemuan } \\
\text { ke: }\end{array}$ & Materi & Kegiatan \\
\hline \multirow[t]{4}{*}{ Ke. } & 10. & $\begin{array}{l}\text { Pendahuluan (Model } \\
\text { belajar BERMUTU) }\end{array}$ & $\begin{array}{l}\text { Pertemuan dihadiri berbagai unsur pimpinan (ka UPTD, } \\
\text { Kep Sekolah Pengawa) menyampaikan aturan-aturan, } \\
\text { sangsi dan hasil belajar BERMUTU. }\end{array}$ \\
\hline & 2 & Identifikasi Masalah & $\begin{array}{l}\text { Penyampain materi sesuai dengan konsep PTK, diawali } \\
\text { dengan penjelasan tentang konsep identifikasi masalah } \\
\text { diakiri dengan tanya jawab. }\end{array}$ \\
\hline & 3 & Perencanaan tindakan & $\begin{array}{l}\text { Menyampaikan perbedaan RPP untuk pembelajaran } \\
\text { berbasis PTK dengan RPP standar. }\end{array}$ \\
\hline & 4 & Pelaksaan tindakan & $\begin{array}{l}\text { Dijelaskan tentang perbedaan pembelajaran berbasis PTK } \\
\text { dengan pembelajaran yang umum }\end{array}$ \\
\hline \multirow{4}{*}{2} & 5 & Analisis dan interpretasi & $\begin{array}{l}\text { Dijelaskan makna anlisis, dan interpretasi, serta cara- } \\
\text { caranya }\end{array}$ \\
\hline & 6 & Refleksi dan tindak lanjut & $\begin{array}{l}\text { Dijelaskan makna refleksi dan tindak lanjut dalam } \\
\text { pembelajaran berbasis PTK. }\end{array}$ \\
\hline & 7 & Penyusunan Laporan & $\begin{array}{l}\text { Dijelaskan komponen-komponen yang harus dilaporkan } \\
\text { dari pembelajaran berbasis PTK. }\end{array}$ \\
\hline & 8 & $\begin{array}{l}\text { Penyusunan laporan } \\
\text { (lanjutan) }\end{array}$ & $\begin{array}{l}\text { Diberikan contoh laporan-laporan PTK, diadakan tanya } \\
\text { jawab }\end{array}$ \\
\hline
\end{tabular}


pengalaman masa lalu ke dalam merencanakan kegiatan proses dan pelaksanaan proses, serta evaluasi dilakukan bersama antara fasilitator dengan peserta, (semua guru di sekolah tempat pelatihan, 10-30 orang); (3) pengorganisasian fleksibel, disesuaikan dengan kondisi dan situasi guru-guru SD terpencil; (4) pelatihan dilaksanakan di SD terpencil (tempat bertugas peserta pelatihan) setiap hari sabtu, selama dua bulan; (5) langkah kegiatan; pertemuan pertama diawali dengan mengajak peserta merenung kembali niat dan tujuan menjadi guru, memotivasi diri untuk menjadi guru yang profesional dengan diajak menonton tayangan-tayangan film yang menceritakan sekolah SD terpencil, guru bercerita tenang pengalamnnya mengajar, dibacakan cerita guru mengajar di SD terpencil yang diuraikan pada buku Indonesia mengajar; dan (6) pertemuan berikutnya, membahas materi seperti yang sudah dirancang untuk model belajar BERMUTU, hanya saja dalam setiap pertemuan, kegiatan diawali dengan apersepsi untuk memahami kelebihan dan kekurangan guru-guru dalam pembelajaran sekaligus dapat menumbuhkan motivasi internal guru-guru dengan beberapa kegiatan seperti mengajak peserta untuk menceritakan pengalaman, kesan dan pesannya menjadi gurudiSD terpencil(dalam setiap pertemuan bergantian), dibacakan puisi atau menyanyikan lagu yang dapat membangkitkan semangat, menceritakan kembali/memberi tanggapan terhadap film-film tentang pendiidkan di SD terpencil yang pernah ditontonnya, menyampaikan cerita yang dimuat dalam buku Indonesia Mengajar. Dengan demikian materi pelatihan dirancang pada Tabel 2 .

\section{Tabel 2. Jadwal dan Proses Kegiatan Pelatihan Kelompok Eksperimen}

\begin{tabular}{|c|c|c|}
\hline $\begin{array}{l}\text { Minggu/per } \\
\text { temuan ke: }\end{array}$ & Materi & Kegiatan \\
\hline क्. & $\begin{array}{l}\text { 1.Pendahuluan } \\
\text { (Model Belajar } \\
\text { BERMUTU }\end{array}$ & $\begin{array}{l}\text { Pertmuan pertama dihadiri oleh kepala sekolah untuk memberikan motivasi } \\
\text { pada guru. Acara dilanjutkan dengan pemutaran Film tentang perjuangan } \\
\text { guru di SD terpencil, ditanggapi oleh para guru, dibahas juga pentingnya } \\
\text { para guru untuk terus meningkatkan kinerja dengan cara selalu berusaha } \\
\text { memecahkan permasalah belajar siswa; }\end{array}$ \\
\hline 3. & $\begin{array}{l}\text { 3.Perencanaan } \\
\text { Tindakan }\end{array}$ & $\begin{array}{l}\text { Masing-masing guru menceritakan bagaimana selama ini membuat rencana } \\
\text { pembelajaran, sama-sama mengkaji kelemahan dan kelebihannya, sampai } \\
\text { pada penjelasan RPP dalam model belajar BERMUTU }\end{array}$ \\
\hline 4. & $\begin{array}{l}\text { 4.Pelaksanaan } \\
\text { Tindakan }\end{array}$ & $\begin{array}{l}\text { Kepada guru yang sudah menyatakan siap untuk jadi model dipersilahkan } \\
\text { untuk mengajar sesuai dengan RPP (berbasis PTK), disaksikan oleh } \\
\text { guru lain (open class), setelah selesai dilanjutkan dengan diskusi, untuk } \\
\text { meningkatkan pemahaman guru-guru terhadap pelaksanaan tindakan kelas. }\end{array}$ \\
\hline 5. & $\begin{array}{l}\text { 5.Analisi dan } \\
\text { Interpretasi }\end{array}$ & $\begin{array}{l}\text { Disampaikan oleh guru-guru kelebihan dan kekurangan pembelajaran } \\
\text { berbasis PTK, yang telah dicobakan pada pertemuan ke 4, dibandingkan } \\
\text { dengan pembelajaran yang sudah biasa di-lakukan, masing-masing guru } \\
\text { menyusun hasil analisisnya dan mencoba meng-intrepretasikannya. }\end{array}$ \\
\hline 6. & $\begin{array}{l}\text { 6. Refleksi dan } \\
\text { tindak lanjut }\end{array}$ & $\begin{array}{l}\text { Hasil analisis dan interpretasi pada pertemuan ke } 5 \text { disampaikan oleh ma- } \\
\text { sing-masing guru, kemudian disampaikan kekurang-kekurangan yang } \\
\text { harus diper-baiki sebagai bahan membuat RPP dan tindak lanjut pada } \\
\text { pembelajaran berikutnya. }\end{array}$ \\
\hline 7. & $\begin{array}{l}\text { 7.Menyusun } \\
\text { laporan }\end{array}$ & $\begin{array}{l}\text { Sebelum mendiskusikan bagaimana melaporkan pembelajaran berbasis } \\
\text { PTK, terlebih dahulu dilakukan pembelajaran berdasarkan RPP hasil } \\
\text { repleksi pada pertemuan ke } 6 \text {. Selanjutnya membahas tentang pelaporan } \\
\text { yang diawali dengan meminta setiap guru peserta pelatihan menyampaikan } \\
\text { pengalaman menulis sebuah artikel atau yang lainnya }\end{array}$ \\
\hline 8. & $\begin{array}{l}\text { 8.Menyusun } \\
\text { laporan } \\
\text { (lanjutan) }\end{array}$ & $\begin{array}{l}\text { Membahas cara-cara menyusun laporan PTK dengan mengajak peserta } \\
\text { untuk latihan merumuskan masing-masing komponen laporan (setiap } \\
\text { komponen dikerjakan secara kelompok yang telah dipilih secara aklamasi) }\end{array}$ \\
\hline
\end{tabular}




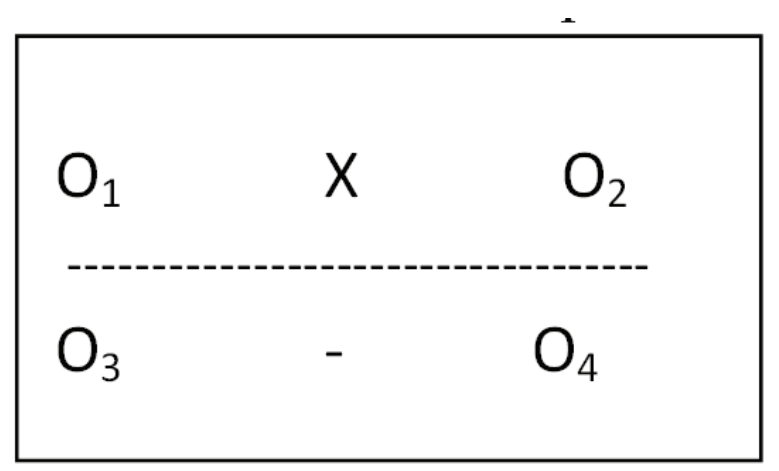

Gambar 4. Model eksperimen

Dari tabel tersebut di atas dapat dijelaskan bahwa, setiap pertemuan diawali dengan menyampaikan kata-kata yang membangkitkan motivasi oleh pelatih dan atau oleh peserta. Pada pertengahan kegiatan pelatihan selalu mengadakan ice breaking dengan cara menceritakan pengalaman yang menarik selama jadi guru di SD terpencil, pengalaman lainnya yang menarik yang dapat dijadikan inspirasi untuk meningkatkan kinerja, memutar film-film tentang pendidikan (diciptakan suasana santai, boleh sambil makan-makan).

Setelah model belajar adaptif divalidasi oleh para guru SD terpencil, instansi terkait (Kabid Dikdas, Ketua LPMP), dan para pakar pendidikan (dosen FKIP), maka dilakukan eksperimen untuk menguji keefektifan model belajar BERMUTU adaptif dalam meningkatkan kinerja guru SD terpencil. Model eksperimen yang digunakan Nonequivalent Control Group Design, adalah model eksperimen yang tidak melakukan random dalam memilih kelompok eksperimen dan kelompok kontrol.

Eksperimen dilakukan untuk mencari pengaruh Model Belajar BERMUTU Adaptif dalam meningkatkan kinerja guru SD terpencil. Untuk itu dipilih 4 SD terpencil yang memili kesamaan akses sekolah dari kota kecamatan ke SD terpencil, sarana prasarana, jumlah guru (minimal 10 orang), kualifikasi guru beragam, dan pengalaman pelatihan program BERMUTU masih terbatas. Keempat SD dibagi 2. Dua SD sebagai kelompok perlakuan dan 2 SD lagi sebagai kelompok kontrol. Terhadap kelompok perlakuan diberikan pelatihan model belajar BERMUTU adaptif, dan kepada kelompok kontrol diberi pelatihan model belajar BERMUTU. Keterangan model eksperimen: $\mathrm{O} 1$ dan $\mathrm{O} 2$ adalah kinerja guru sebelum diberikan pelatihan, O2 dan $\mathrm{O} 4$ adalah kinerja setelah diberi pelatihan selama 8 kali pertemuan. Kinerja diukur dengan instrumen tentang pemahaman dan penerapan PTK oleh guru-guru dalam pelaksanaan pembelajaran. Aspek penilaiannya adalah: membuat tulisan tentang pengalaman mengajar di SD terpencil, pemahaman tentang konsep PTK, memahami langkah-langkah pembelajaran berbasis PTK, memahami kajian pembelajaran, membuat kajian pembelajaran, memahami identifikasi masalah,

Tabel. 3 Skor Hasil Penelitian pada Kelompok Kontrol dan Eksperimen

\begin{tabular}{|c|c|c|c|c|c|c|c|}
\hline \multicolumn{8}{|c|}{ Kelompok } \\
\hline \multicolumn{4}{|c|}{ Kontrol } & \multicolumn{4}{|c|}{ Eksperimen } \\
\hline \multirow[t]{2}{*}{ Responden } & \multicolumn{3}{|c|}{ Skor } & \multirow[t]{2}{*}{ Responden } & \multicolumn{3}{|c|}{ Skor } \\
\hline & $\mathrm{O}$ & $\mathrm{O}$ & Gain & & $\mathrm{O}$ & $\mathrm{O}$ & Gain \\
\hline 1. STD & 4 & 7 & 3 & 1.HIY & 2 & 6 & 4 \\
\hline 2. JONA & 3 & 5 & 2 & 2. KhA & 3 & 7 & 4 \\
\hline 3. SWN & 2 & 4 & 2 & 3.SKY & 2 & 7 & 5 \\
\hline 4. $\mathrm{RF}$ & 3 & 5 & 2 & 4.SMY & 2 & 6 & 4 \\
\hline 5. HRMN & 2 & 5 & 3 & 5.DDH & 2 & 7 & 5 \\
\hline 6. SYTN & 2 & 4 & 2 & 6.SLA & 3 & 7 & 4 \\
\hline 7. NRTN & 3 & 6 & 3 & 7.SPD & 3 & 8 & 5 \\
\hline 8. SRNT & 2 & 4 & 2 & 8.PSY & 2 & 7 & 5 \\
\hline 9. SMIN & 2 & 6 & 4 & 9.MAD & 2 & 6 & 4 \\
\hline 10. IDH & 3 & 7 & 4 & 10.RT & 3 & 7 & 4 \\
\hline 11.JHS & 3 & 6 & 3 & 11.RMD & 3 & 8 & 5 \\
\hline 12.MHT & 2 & 5 & 3 & 12.ISR & 3 & 8 & 5 \\
\hline 13.MTR & 2 & 5 & 3 & 13.SWR & 3 & 7 & 4 \\
\hline 14.SHL & 2 & 6 & 4 & 14.ASM & 2 & 6 & 4 \\
\hline 15.EVH & 3 & 6 & 3 & 15.KUH & 2 & 6 & 4 \\
\hline 16.YPL & 3 & 5 & 2 & 16.DSP & 2 & 5 & 3 \\
\hline 17.SLD & 2 & 3 & 1 & 17.EFA & 2 & 6 & 4 \\
\hline 18.DWA & 2 & 3 & 1 & 18.ENDI & & 6 & 4 \\
\hline 19.SMS & 2 & 4 & 2 & 19.HRA & 2 & 4 & 2 \\
\hline \multirow[t]{2}{*}{ 20.RBM } & 2 & 5 & 3 & 20.AA & 2 & 5 & 20 \\
\hline & & & 2,2 & & & & 4,05 \\
\hline
\end{tabular}


Tabel 4 Skor Perhitungan untuk Analisis Hipotesis

\begin{tabular}{lllllll}
$\mathbf{R e s p}$ & $\mathbf{X}_{\mathbf{i} 1}$ & $\mathbf{X}_{\mathbf{i k}}$ & $\mathbf{x}_{\mathbf{i}}$ & $\mathbf{x}_{\mathbf{i}}$ & $\mathbf{x}_{\mathbf{i}}{ }^{2}$ & $\mathbf{x}_{\mathbf{i}}{ }^{2}$ \\
\hline 1 & 3 & 4 & 0,8 & $-0,05$ & 0,64 & 0,0025 \\
2 & 2 & 4 & $-0,2$ & $-0,05$ & 0,04 & 0,0025 \\
3 & 2 & 5 & $-0,2$ & 0,95 & 0,04 & 0,9025 \\
4 & 2 & 4 & $-0,2$ & $-0,05$ & 0,04 & 0,0025 \\
5 & 3 & 5 & 0,8 & 0,95 & 0,64 & 0,9025 \\
6 & 2 & 4 & $-0,2$ & $-0,05$ & 0,04 & 0,0025 \\
7 & 3 & 5 & 0,8 & 0,95 & 0,64 & 0,9025 \\
8 & 2 & 5 & $-0,2$ & 0,95 & 0,04 & 0,9025 \\
9 & 4 & 4 & 1,8 & $-0,5$ & 3,34 & 0,0025 \\
10 & 4 & 4 & 1,8 & $-0,5$ & 3,24 & 0,0025 \\
11 & 3 & 5 & 0,8 & 0,95 & 0,64 & 0,9025 \\
12 & 3 & 5 & 0,8 & 0,95 & 0,64 & 0,9025 \\
13 & 3 & 4 & 0,8 & $-0,5$ & 0,64 & 0,0025 \\
14 & 4 & 4 & 1,8 & $-0,5$ & 3,24 & 0,0025 \\
15 & 3 & 4 & 0,8 & $-0,5$ & 0,64 & 0,0025 \\
16 & 2 & 3 & $-0,2$ & $-1,05$ & 0,04 & 1,1025 \\
17 & 1 & 4 & $-1,2$ & $-0,5$ & 1,44 & 0,0025 \\
18 & 1 & 4 & $-1,2$ & $-0,5$ & 1,44 & 0,0025 \\
19 & 2 & 2 & -02 & $-2,05$ & 0,04 & 4,2025 \\
20 & 3 & 2 & 0,8 & $-2,05$ & 0,64 & 4,2025 \\
$\mu$ & 2,20 & 4,05 & & & 13,80 & 14,956 \\
\hline & & & & & $\mathrm{S}^{2}=0,69$ & $\mathrm{~S}^{2}=0,75$ \\
\hline
\end{tabular}

menyusun identifikasi masalah berbasis PTK. Menyusun rencana pembelajaran, melaksanakan pembelajaran berbasis PTK, memahami fungsi observasi dalam pembelajaran, memahami cara mengumpulkan data, memahami cara menganalisis data, memahami cara melakukan refleksi dan tindak lanjut, memahami cara membuat proposal PTK, memahami cara membuat laporan PTK, membuat laporan PTK/artikel ilmiah tentang pembelajaran/ menulis pengalaman belajar.

Untuk mengetahui pengaruh model Belaja BERMUTU adaptif terhadap kinerja guru SD terpencil, adalah memberikan penilaian (menggunakan instrumen tersebut di atas) sebelum pelatihan $(\mathrm{O} 1, \mathrm{O} 3)$ dan sesudah pelatihan $(\mathrm{O} 2, \mathrm{O} 4)$. Skor hasil penilaian terhadap dua kelompok responden (lihat tabel 3).

Terhadap skor kedua kelompok tersebut dia atas dilakukan analisis perbedaan dengan rumus $\mathrm{t}$ test sebagi berikut:

$$
\mathrm{t}=\frac{\mu_{1}-\mu_{2}}{\sqrt{\frac{s_{1}{ }^{2}}{n_{1}}+\frac{s_{2}{ }^{2}}{n_{2}}}}
$$

Berdasarkan rumus $t$ test maka di-lakukan perhitungan pada tabel 4.

Analisis perbedaan sebagai berikut:

Diketahui:

$$
\begin{aligned}
& \mathrm{n}=20 \\
& \mu_{\mathrm{e}}=4,05 \\
& \mu_{\mathrm{k}}=2,2 \\
& \mathrm{~s}^{2} \mathrm{e}=0,75 \quad \mathrm{~s}^{2}=0,69
\end{aligned}
$$

$$
\begin{aligned}
& \text { Maka: } \\
& \mathrm{t}=\frac{4,05-2,20}{\sqrt{\frac{0,75}{20}+\frac{0,69}{20}}}=26,43
\end{aligned}
$$

Hipotesis yang diajukan adalah:

$\mathrm{H}_{\mathrm{o}}: \mu_{\mathrm{e}}=\mu_{\mathrm{k}}$ :Tidak ada perbedaan kemampuan guru SD terpencil dalam pem-belajaran berbasis PTK yang dilatih dengan model belajar BERMUTU adaptif dan model belajar BERMUTU

$\mathrm{H}_{\mathrm{A}}: \mu_{\mathrm{e}}>\mu_{\mathrm{k}}$ : Kemampuan guru SD terpencil dalam pembelajaran berbasis PTK yang dilatih dengan model belajar BERMUTU adaptif lebih tinggi daripada kinerja guru SD terpencil yang dilatih dengan model belajar BERMUTU. Uji hipotesis, Jika $t_{h}>t_{t}$ maka Ho di tolak.

Dengan $\alpha 0,05 \mathrm{dk}$ n-1 $=19$, maka diperoleh $t_{t}=2,093$. Diketahui $t_{h}=26,43$ jadi $t_{h}>t_{t}$, maka $\mathrm{H}_{\mathrm{o}}$ ditolak . Dengan demikian kemampuan guru SD terpencil dalam pembelajaran berbasis PTK yang dilatih dengan model belajar BERMUTU adaptif lebih tinggi dari pada Guru SD terpencil yang dilatih dengan model belajar BERMUTU. Hal ini berarti Model Belajar BERMUTU Adaptif lebih efektif dalam meningkatkan kinerja guru SD terpencil, daripada Model Belajar BERMUTU. Kondisi tersebut dikuatkan pada hasil penelitian yang dilakukan oleh (Sudarnoto. 2010) yaitu kepercayaan diri, komitmen terhadap karir sebagai guru dan kemampuan mengelola kelas memberikan efek langsung terhadap kualitas kehidupan kerja. 


\section{SIMPULAN DAN SARAN}

\section{Simpulan}

Berdasarkan analisis data dan pembahasannya, dapat disimpulkan sebagai berikut. Pertama Data empirik, kondisi dan situasi pembelajaran di SD terpencil, serta keterbatasan kualifikasi dan pengalaman guru dalam me-laksanakan pembelajaran serta keterbatasan pelatihan untuk meningkatan kompetensi profesional, mengharuskan dikembangkannya model belajar BERMUTU adaptif bagi guru di SD terpencil. Kedua, telah dirancang dan diujicobakan model belajar BERMUTU adaptif sebagai upaya untuk meningkatkan kinerja guru SD terpencil. Ketiga. Hasil uji coba model membuktikan, bahwa guru SD terpencil yang dilatih dengan meng-gunakan model belajar BERMUTU adaptif lebih tinggi kemampuannya dalam memahami dan menerapkan pembelajaran berbasis PTK dibandingkan dengan guru SD terpencil yang dilatih dengan model belajar BERMUTU. Hal ini membuktikan bahwa model belajar BERMUTU adaptif lebih efektif dalam meningkatkan kinerja guru SD terpencil.

\section{Saran}

Tidakmudahuntukmengupayakanpembelajaran di SD terpencil secara kondusif, karena kondisi dan situasi SD terpencil dengan segala keterbatasan sarana prasarana dan/atau aksesbilitas, sementara tuntutan untuk meningkatkan kinerja guru tidak bisa ditawar tawar. Oleh karena itu kepada pihak terkait; Disdiknas, khususnya Kabid PTK, LPMP dalam menerapkan model Belajar BERMUTU (Replika Program BERMUTU) di SD terpencil tidak cukup dengan memanggil guru-guru (dengan jumlahnya yang dibatasi) untuk mengikuti pelatihan di Kota Provinsi seperti yang selama ini dilakukan. Tetapi harus dibuat program untuk melakukan pelatihan di daerah terpencil yang diperuntukan bagi semua guru SD terpencil.

Pelatihan model belajar BERMUTU yang saat ini masih diterapkan oleh LPMP, (Replikasi BERMUTU), masih bersifat standar yakni memanggil guru-guru SD terpencil untuk dilatih di kota Provinsi. Disarankan agar pihak yang terkait seperti LPMP, Disdiknas, khusunya Kabid PTK untuk melaksanakan pelatihan dengan cara mendatangi SD terpencil, dengan menggunakan dan mengembangkan konsep pelatihan yang memper-timbangkan fakta empirik situasi dan kondisi guru SD terpencil.
Sebagai alternatif, model belajar BERMUTU adaptif dapat dijadikan pertimbangan untuk dipedomani dan atau digunkan untuk melatih guru-guru SD terpencil dalam meningkatkan kemampuannya mengembangkan proses pembe-lajaran berbasisi PTK.

Untuk menggunakan model belajar BERMUTU adaptif diperlukan kekuatan motivasi internal guru-guru, Oleh karena itu kepada guru-guru SD terpencil khusunya yang sudah berstatus PNS dan telah memperoleh tunjangan profesi, sudah seharusnya memberikan contoh bagi guru-guru honor dalam meningkatkan motivasi internal sebagai guru profesional. Guru PNS harus mengurangi kemangkiran menjalankan tugas, kurangi mendelegasikan/membebankan semua tugas kepada guru honor. (ditemukan guru guru PNS di SD terpencil, mengajar hanya satu kali dalam seminggu, bahkan ada yang satu hari dalam sebulan, Mereka disibukan dengan kegiatan lain di luar profesinya).

\section{DAFTAR RUJUKAN}

Alwani, M. 2012. Implementasi Pro-gram KKG (Kelompok Kerja Guru) Dalam Meningkatkan Kompetensi Guru SD (Studi Kasus KKG BERMUTU Ki Ageng Selo Kec. Klambu Kab Grobongan). Tesis tidak diterbitkan. Semarang: IAIN Walisongo.

Aritonang, K.T. 2005. Kompensasi Kerja, Disiplin Kerja Guru dan Kinerja Guru SMP Kristen BPK PENEBUR Jakarta. Jurnal Pendidikan Penabur. 4 (4), 1-16.

Bahri, S. 2011. Faktor yang Mempengaruhi Kinerja Guru SD di Dataran Tinggi Moncong Kabupaten Gowa Provinsi Sulawesi Selatan. Jurnal MEDTEK. 3(2):1-11

Basuki, I. A. 2013. Beban Kerja Guru dalam Kegiatan Kependidikan di Daerah yang mendapat Program Bermutu. Jurnal Ilmu Pendidian. 40(1):81-92

Direktorat Pembinaan Pendidikan dan Pelatihan. 2008. Bahan Belajar Mandiri Program Belajar BERMUTU. Jakarta: Departemen Pendidikan Nasional.

Hanafi, A \& Yuliani, I. 2006. Faktor-faktor yang Mempengaruhi Kinerja Guru Matematika dalam Pelaksanaan Kurikulum Berbasis Kompetensi (KBK) pada Sekolah Menengah Atas Kota Palembang. Jurnal Manajemen \& Bisnis. 4 (7), 1-19. 
Hurmaini, M. 2011. Dampak Pelaksanaan Sertifikasi Guru terhadap Peningkatan Kinerja Guru dalam Proses Pembelajaran: Studi pada Madrasah Tsanawiyah Negeri Kota Jambi. Media Akademika. 26 (4), 499-535

Khodijah, N. 2013. Kinerja Guru Madrasah dan Guru Pendidikan Agama Islam Pasca Sertifikasi di Sumatera Selatan. Cakrawala Pendidikan. 32 (1), 91-102

Montgomery, D. C. 2001. 5th Ed, Design and Analysis of Experiments. New York: JohnWiley \& Sons, Inc.

Nurhayati, B. 2006. Faktor-Faktor yang Mempengaruhi Profesionalisme dan Kinerja Guru Biologi di SMAN Kota Makassar Sulawesi Selatan. Mimbar Pendidikan. 25 (4), 64-70
Sudarnoto. 2010. Upaya Meningkatkan Kualitas Kehidupan Kerja Guru Sekolah Dasar. Jurnal Sekolah Dasar. 19(2):44-56.

Sugiyono. 2013. Metode Penelitian Kuantitatif Kualitatif dan $R \& D$. Bandung: Alfabeta.

Susilawati. 2014. Upaya Mengembangkan Profesionalitas Guru Melalui Implementasi dan Supervisi Kepala Sekolah di SD. Jurnal Ilmu Pendidikan. 41(2).

Sutisna, A. 2011. Pelatihan Berbasis Kinerja: Konsep dan Implementasi dalam Pelatihan Guru/Tutor. Jakarja: Universitas Negeri Jakarta. 